\title{
BEHR, Gustavo. Bairro Alto. Cidade Baixa. Lisboa- Porto Alegre. Outros destinos. Lisboa: Chiado, 2017. $317 p$.
}

\author{
BEATRIZ WEIGERT \\ Pontifícia Universidade Católica do Rio Grande do Sul. Porto Alegre, RS, Brasil.
}

"Se tivesses lido o que li, combinado com o que presenciei, talvez ficasses no meu estado."

Gustavo BeHR

Gustavo Behr, tendo já intervindo em congressos, seminários e eventos sobre a Imigração e direitos dos cidadãos, oferece-nos, agora, sua primeira publicação em livro. Não se constitui, entretanto, de informação e pesquisa sobre formas de conduta e solidariedade, mas sobre deambulações e vivências na vida.

Trata-se, isto sim, de caminharmos pelas ruas do Bairro Alto de Lisboa e da Cidade Baixa de Porto Alegre, e sermos testemunhas do que por aqueles espaços ocorre. Para já, atente-se na felicidade do título do livro, que põe em relevo a oposição dos adjetivos de dois locais aliciantes. E, enquanto o chamamento pricipal é para as duas metrópoles, prometem-se outros percursos para os quais o leitor se vai preparando.

O conteúdo do livro desenvolve-se a partir da aquiescência de um estudioso à solicitação de uma editora, para a seleção de textos de um escritor. Assim, o que se lê em Bairro Alto. Cidade Baixa principia na organização de três blogs de Guglielmo Walden Bernardo por Paul Grimaldi. Isto não significa que seja aí o seu limite. Na verdade, Paul tem um bocado de dificuldade para movimentar-se por entre o concreto e o abstrato dos desabafos de Guglielmo. Estados de alma e experiências familiares conjugam-se de tal forma que o relator reflete que

\footnotetext{
Vendo bem, a própria antologia que estava a preparar era uma espécie de álbum de fotografias, retratos de momentos, uma coleção de histórias e estórias gravadas quase como imagens (p.209).
}

De maneira misteriosa, em passeio pelo Parque da Redenção em Porto Alegre, Guglielmo é instigado a visitar a Avenida Bagé, 1220, de onde ressurgem figuras do passado (p.39), que reaparecem em "Mapas de
Abraços". E mesmo em "O caminho faz-se caminhando" vem a constatação de um aprendizado, pois "esqueceu-se de que não sabia andar e deu alguns passinhos" (p.211).

É que o bloguista vai temperando a realidade com arroubos da imaginação. Inclui, nos seus dados, tantas ocorrências oníricas, que forçam Paul a buscar um modo de apresentação aceitável. E, então, desobedecendo pontuações cronológicas, opta por reunir os temas que as lembranças acumularam ao sabor das idades.

A tarefa porém adensa-se porque o estudioso dos textos, ele mesmo, resolve ir em busca do autor, no intuito de seguir-lhe os passos e "conhecer mais de perto a atmosfera de alguns dos seus blogs" (p.29). O principal desafio é a descoberta do lugar em que Lisboa e Porto Alegre encontram-se: a ligação da Rua da Rosa no 187 , com a rua Lima e Silva, no 430. Anota: "Dá que pensar qual é o ponto onde a Lima e Silva cruza com a Rua da Rosa" (p. 27). Será que existe ? Que esquina será essa?

Paul viaja, procurando ampliar o conhecimento sobre o dono dos blogs. Aporta na América do Sul e vai a Porto Alegre, São Paulo, Rio de Janeiro, Buenos Aires e Colônia do Sacramento. O estudioso tenta percorrer os lugares por onde Guglielmo passara. Consegue encontrar pessoas que haviam tido contato com o escritor, vê livros publicados por ele, e até sua "grafia" na dedicatória à obra O ladrão de memórias, pertencente ao Bar Memória (p.96), de Colónia do Sacramento. Em certo momento, Paul sente-se um outro Guglielmo. Parece estar a confundir pensamentos. De volta a Lisboa, Paul "pondera viajar a alguma das cidades europeias mencionadas nos blogs do autor" (p.159). Vai a Barcelona e a Veneza "Está à procura do Senhor Antoni? (p. 162) - "Quer vir jantar conosco? Vamos a San Marco" (p. 172). Mas nessas cidades, ninguém o ajuda a obter mais informações sobre Guglielmo (p. 177). 
Já então passamos a ler em Bairro Alto. Cidade Baixa, além da publicação dos blogs de Guglielmo Bernardo Walden, a história das viagens de Paul Grimaldi. E damo-nos conta de que são três as vozes que se complementam na narrativa: é a fala do narrador (onisciente), a de Paul e a de Guglielmo. Em verdade é o narrador que conduz o relato. Ele sabe tudo, lê pensamentos e desejos e vai atento à movimentação de Paul Grimaldi.

O cuidado com a beleza está presente na obra, desde à escolha do local para desenvolver o trabalho. $\mathrm{O}$ encantamento da paisagem. A vista da cidade enternece, a música embala, o vinho agrada o paladar. E já nas primeiras páginas do livro, o tratamento do conteúdo é-nos revelado pela revoada de borboletas: "As memórias também eram como borboletas?" (p.23). "Era um arcoíris em movimento" (p.23).

Artes plásticas e artes musicais conjugam-se para alegrar os ambientes por onde passamos. Guglielmo discorre sobre o contato com as cores e os sons. Considera que os quadros reunidos podem compor um só e mesmo desenho (p.201). As cores sobrepõem-se e os motivos podem refazer-se. (p.203). Esquecendo tintas e pinceis, volta-se para as guitarras e, com entusiasmo, descreve a hora da criação. Afinal, no anseio pela melodia, "ao primeiro toque da palheta nas cordas da guitarra sente a música a pairar no ar" (p.242). Eis que encontra "a ponta do nó, uma semente que começa a crescer, a florescer, a espalhar-se pelo chão, a subir pelas paredes e a tomar todas as divisões do apartamento" (p.242). E a ouvinte

Rendeu-se em segundos, quando viu, ela própria, a videira musical que saía da guitarra e aromatizava o espaço, saltando pelas frestas das janelas, cantando aquela música contagiante (p. 242).

E mais tarde confirma-se: "Sigo o caminho de uma vinha que se inicia no Miradouro da Graça e prossegue por um labirinto musical" (p.243).

Tanto como tem-se o dinamismo da escrita, na alternância de mãos e vozes, aprecia-se o dinamismo das ações na narrativa, com o trânsito de personagens de uma geografia à outra. Viagens realizam-se, mas também as deambulações contínuas revelam avenidas, ruas, miradouros e jardins. Burburinho, pressa, vozerio, pregões, multidão.

Assim percorrem-se paragens de Lisboa e Porto Alegre, observando hábitos, cenários e cultura.

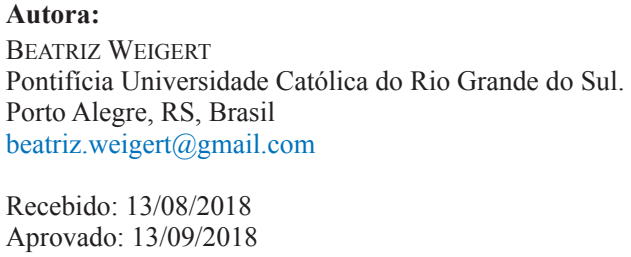

Recebido: 13/08/2018

Aprovado: 13/09/2018 